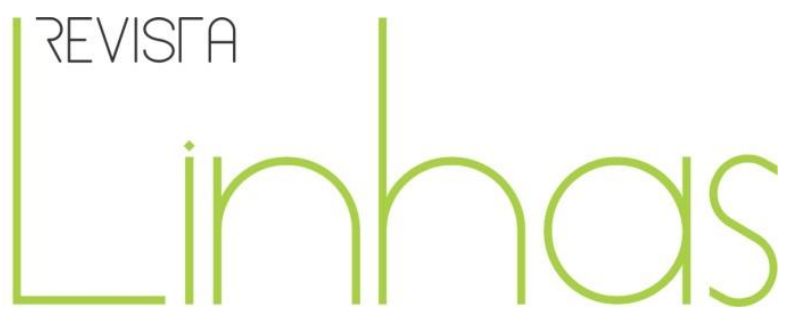

\title{
Resenha do livro "Política e poética das imagens como processos educativos"
}

FERRARI, Anderson; CASTRO, Roney Polato de. (orgs). Política e poética das imagens como processos educativos. Juiz de Fora: Ed. UFJF, 2012, 244p. (Caminhos da pesquisa educacional). ISBN: $978857672149-9$.

Ricardo Desidério da Silva

Universidade Estadual do Paraná - UNESPAR - PR/Brasil contatodesiderio@hotmail.com

\section{Para citar esta resenha:}

SILVA, Ricardo Desidério da. Resenha do livro Política e poética das imagens como processos educativos. Revista Linhas. Florianópolis, v. 17, n. 34, p. 361-364, maio/ago. 2016.

DOI: $10.5965 / 1984723817342016361$

http://dx.doi.org/10.5965/1984723817342016361 
Este livro, organizado por Anderson Ferrari e Roney Polato de Castro, traduz encontros, reflexões e escritas do Grupo de Estudos em Gênero, Sexualidade, Educação e Diversidade (GESED - PPGE/UFJF). Como desafio, proposto pelo próprio GESED, os textos se articulam ao surpreendente mundo do cinema, que além de sua combinação com a escrita, nos leva também ao fascínio das imagens e sons em movimento.

O livro "Política e poética das imagens como processos educativos", lançado e publicado pela Editora UFJF, foi publicado no ano de 2012. A edição contém 244 páginas, sendo que as últimas seis são destinadas à apresentação dos autores. Estes autores, por si só, já se constituem como valiosas contribuições para a obra. O prefácio, escrito por Rosália Maria Duarte da PUC-RJ, dá início à produção, que segue com uma introdução escrita pelos organizadores, denominada "Política e Poética das Imagens: implicações para o campo da educação", que nos possibilita e instiga ainda mais a leitura dos textos que fizeram parte das reflexões do grupo GESED. Composto por onze capítulos, que apontam para compreensão da relação entre Cinema, Cultura Visual e Educação, os escritos são elaborados por autores de diferentes áreas do conhecimento, mas interligados às problematizações das imagens, gênero, sexualidade, diversidade e educação, numa perspectiva pós-estruturalista.

Nesta obra, os autores nos convidam, a partir das imagens e seus discursos, a nos questionarmos sobre as práticas culturais que educam o nosso olhar e sobre os efeitos desse olhar sobre cada um de nós. Para tanto, em seu aspecto político, os próprios audiovisuais nos inserem em um discurso que é construído através de imagens e sons a partir dos filmes selecionados (Mademoiselle Chambon; Como crianças na Terra: toda criança é especial; Uma família bem diferente; Terra Fria; O sorriso de Mona Lisa; Antonia; Billy Elliot; O Closet; $X X Y$ ). Esse discurso, por sua vez, nos leva a novos e múltiplos significados que vão sendo internalizados como uma verdade (por nós espectadores). Porém, são essas "realidades" que cada texto apresentado neste livro, que problematizam e nos colocam sob suspeita de pensarmos sobre nós mesmos e sobre os outros.

E este pensar, proporcionado através das imagens, dos cortes de cada cena e até mesmo dos silêncios existentes no filme, nos conduz ao seu aspecto poético. Para os 
autores, falar "do aspecto poético das imagens, desse espaço de resistência e de negociação que está aberto à intervenção daquele que olha, é dar voz ao sentido cultural que todo olhar comporta, como expressão das subjetividades presentes na operação cultural de olhar" (FERRARI e CASTRO, 2012, p. 15).

Uma das apostas do livro, como já mencionado anteriormente, é seu olhar atento ao "silêncio" de cada filme. Ferrari (2012), em seu texto, "Politicamente Silenciosa": Cinema e a Formação Ética-Estética dos Sujeitos, aponta que estes espaços são de liberdade e de intervenção do espectador. Para o autor, quando "preenchemos esses espaços de silêncio, não estamos mais falando do filme, mas de nós mesmos, de maneira que essa relação estabelecida entre filme, silêncio e nós pode servir para problematizar como olhamos" (p. 38).

A estratégia também de se pensar no uso dos audiovisuais é que as imagens educam (ALMEIDA, 1999a, 1999b, 2004; COUTINHO, 2003; MIRANDA, COPPOLA e RIGOTTI, 2005; MIRANDA, 2001, 2008; FERRARI, 2012; SILVA 2015). Neste sentido, ao estabelecermos uma relação entre vídeo e conhecimento, devemos inicialmente ultrapassar o uso dos vídeos apenas como recurso didático ilustrativo, reconhecendo assim o valor educativo.

Afirmar que a linguagem audiovisual é educativa e dizer que algo participa da educação é mostrar que nada é natural, mas apreendido. No caso das imagens, é dizer que vemos porque aprendemos a olhar. Ao longo dos onze capítulos, os filmes selecionados e seus respectivos textos nos convidam também a rever nossos olhares sobre a sexualidade e suas subjetividades, possibilitando repensar os filmes e nós mesmos, e sem dúvidas, este é um dos principais objetivos deste livro a partir da Cultura Visual. 


\section{Referências}

ALMEIDA, Milton José. Cinema: arte da memória. Campinas, SP: Autores Associados, 1999a.

ALMEIDA, Milton José A Educação Visual da Memória: Imagens Agentes do Cinema e da Televisão. Pró-Posições. Vol. 10. N. 2 (29). Julho, 1999b.

COUTINHO, Laura Maria. 0 estúdio de televisão e a educação da memória. Brasília: Plano Editora, 2003.

FERRARI, Anderson; CASTRO, Roney Polato de. (orgs). Política e poética das imagens como processos educativos. Juiz de Fora: Ed. UFJF, 2012, 244p.

FERRARI, Anderson. “Politicamente Silenciosa”: Cinema e a Formação Ética-Estética dos Sujeitos. In: CASTRO, Roney Polato de. (orgs). Política e poética das imagens como processos educativos. Juiz de Fora: Ed. UFJF, 2012, p.37-54.

MIRANDA, Carlos Eduardo Albuquerque; COPPOLA, Gabriela Domingues; RIGOTTI, Gabriela Fiorin. A educação pelo cinema. Rev. Educação e Cinema, Unicamp: SP, p. 02, 2005.

MIRANDA, Carlos Eduardo Albuquerque. Reflexões de um Tempo e Diligências para Metodologias de Estudo de Imagens em Educação. Revista Educação \& Realidade, v. 33, n¹, pp. 99-115, jun/jun, 2008.

MIRANDA, Carlos Eduardo Albuquerque. Uma educação do olho: as imagens na sociedade urbana, industrial e de mercado. Caderno Cedes, Campinas, n. 54, p. 28-40, ago. 2001.

SILVA, Ricardo Desidério. Educação Audiovisual da Sexualidade: olhares a partir do Kit Anti-Homofobia. 2015, 144 f. Tese (Doutorado em Educação Escolar). Faculdade de Ciências e Letras, Universidade Estadual Paulista, Araraquara-SP, 2015.

Recebido em: 13/04/2016 Aprovado em: 02/05/2016

Universidade do Estado de Santa Catarina - UDESC Programa de Pós-Graduação em Educação - PPGE

Revista Linhas

Volume 17 - Número 34 - Ano 2016 revistalinhas@gmail.com 